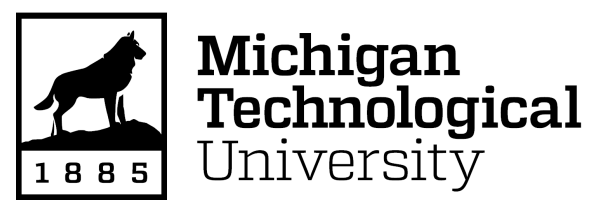

Michigan Technological University Digital Commons @ Michigan Tech

$7-2012$

\title{
An invasive riparian tree reduces stream ecosystem efficiency via a recalcitrant organic matter subsidy
}

\author{
Madeline M. Mineau \\ Idaho State University \\ Colden V. Baxter \\ Idaho State University \\ Amy Marcarelli \\ Michigan Technological University \\ G. Wayne Minshall \\ Idaho State University
}

Follow this and additional works at: https://digitalcommons.mtu.edu/biological-fp

Part of the Life Sciences Commons

\section{Recommended Citation}

Mineau, M. M., Baxter, C. V., Marcarelli, A., \& Minshall, G. W. (2012). An invasive riparian tree reduces stream ecosystem efficiency via a recalcitrant organic matter subsidy. Ecology, 93(7), 1501-1508. http://dx.doi.org/10.1890/11-1700.1

Retrieved from: https://digitalcommons.mtu.edu/biological-fp/12

Follow this and additional works at: https://digitalcommons.mtu.edu/biological-fp

Part of the Life Sciences Commons 


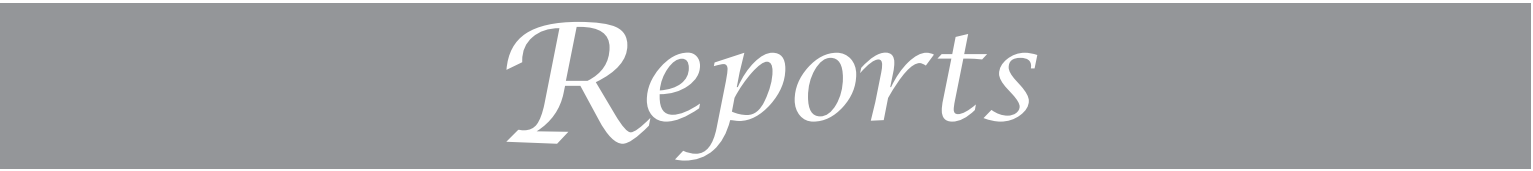

Ecology, 93(7), 2012, pp. 1501-1508

(c) 2012 by the Ecological Society of America

\title{
An invasive riparian tree reduces stream ecosystem efficiency via a recalcitrant organic matter subsidy
}

\author{
Madeleine M. Mineau, ${ }^{1,2,4}$ Colden V. Baxter, ${ }^{1}$ Amy M. Marcarelli, ${ }^{1,3}$ and G. Wayne Minshall ${ }^{1}$ \\ ${ }^{1}$ Stream Ecology Center, Department of Biological Sciences, Idaho State University, Pocatello, Idaho 83209 USA \\ ${ }^{2}$ School of Biology and Ecology, University of Maine, Orono, Maine 04469 USA \\ ${ }^{3}$ Department of Biological Sciences, Michigan Technological University, Houghton, Michigan 49931 USA
}

\begin{abstract}
A disturbance, such as species invasion, can alter the exchange of materials and organisms between ecosystems, with potential consequences for the function of both ecosystems. Russian olive (Elaeagnus angustifolia) is an exotic tree invading riparian corridors in the western United States, and may alter stream organic matter budgets by increasing allochthonous litter and by reducing light via shading, in turn decreasing in-stream primary production. We used a before-after invasion comparison spanning 35 years to show that Russian olive invasion increased allochthonous litter nearly 25 -fold to an invaded vs. a control reach of a stream, and we found that this litter decayed more slowly than native willow. Despite a mean $50 \%$ increase in canopy cover by Russian olive and associated shading, there were no significant changes in gross primary production. Benthic organic matter storage increased fourfold after Russian olive invasion compared to pre-invasion conditions, but there were no associated changes in stream ecosystem respiration or organic matter export. Thus, estimated stream ecosystem efficiency (ratio of ecosystem respiration to organic matter input) decreased $14 \%$. These findings show that invasions of nonnative plant species in terrestrial habitats can alter resource fluxes to streams with consequences for whole-ecosystem functions.
\end{abstract}

Key words: ecosystem efficiency; ecosystem metabolism; Elaeagnus angustifolia; invasive species; organic matter budget; riparian; Russian olive; stream; subsidy.

\section{INTRODUCTION}

Stress experienced by ecosystems due to anthropogenic disturbances often results in altered function and imbalances in energy and nutrient budgets (Rappaport et al. 1985). For example, Odum (1985) hypothesized that stress would cause ecosystems to become more reliant on external sources of energy, increase rates of respiration, shift away from a balance between production and respiration, and increase the amount of unused or exported energy. Most empirical tests of these theories have focused on stressors associated with land use or pollution, such as clear cutting or chronic nutrient addition (Likens et al. 1970, Foster et al. 1997). Species invasions are a primary agent of anthropogenic global change with major implications for native biodiversity (Vitousek et al. 1997), but their consequences as a

Manuscript received 19 September 2011; revised 9 February 2012; accepted 15 February 2012. Corresponding Editor: W. V. Sobczak

${ }^{4}$ E-mail: madeleine.mineau@maine.edu stressor on such whole-ecosystem responses are poorly understood.

Budgets of nutrients or energy are integrative indicators of ecosystem response that encompass multiple functions, such as primary production, ecosystem respiration, organic matter $(\mathrm{OM})$ retention, and $\mathrm{OM}$ processing. Some indices, such as ecosystem efficiency (EE), or the extent to which organic matter inputs are used or respired within the ecosystem, represent the ratio or balance of multiple functions (Webster and Meyer 1997). EE expresses whether a defined ecosystem is a net importer or exporter of OM; a shift in this status can have effects on other ecosystems to which it may be connected by the flow of materials or movements of organisms. Though EE is a fundamental characteristic of ecosystems, few studies have explicitly investigated its resistance to disturbance.

Stream ecosystems are dynamic in their transport of energy, nutrients, and organisms along their flowpaths and also via lateral exchanges with riparian habitat (Fisher et al. 1998). For example, resource subsidies of nutrients, OM, or prey from riparian zones to streams 
can affect macroinvertebrate community structure and productivity (Wallace et al. 1997b), and regulate food web dynamics (Nakano et al. 1999). Streams are typically heterotrophic, with respiration exceeding production, because they receive energy subsidies from terrestrial ecosystems (Marcarelli et al. 2011). However, this is not the norm for streams in arid environments that typically have limited riparian $\mathrm{OM}$ inputs and receive adequate light to fuel in-stream production and as a result may be autotrophic (Minshall 1978, Busch and Fisher 1981). Allochthonous inputs can act as stabilizing factors in aquatic ecosystems (Wetzel 1995). Therefore, forested headwater streams with large allochthonous inputs exhibit low resistance to riparian disturbances, but streams with more diverse energy sources may be less affected by such a disturbance (Webster et al. 1983). Because of their relatively high autochthonous production, streams in arid environments may be more resistant than forested streams to changes in riparian subsidies, though this has not been tested.

Species invasions can alter subsidy exchange between aquatic and terrestrial ecosystems (Baxter et al. 2004). Because riparian plants can control many aspects of stream ecosystems (e.g., light availability, OM and nutrient inputs [Gregory et al. 1991]), invasions in riparian zones have the potential to strongly affect adjacent aquatic ecosystems. For example, Kennedy and Hobbie (2004) found that nonnative saltcedar (Tamarix ramosissima) altered stream OM dynamics by increasing allochthonous litter inputs and decreasing autochthonous primary production. Disturbance of resource subsidies may represent a stress for the recipient ecosystem, but generally has not been considered in this context (but see Fausch et al. 2010).

Russian olive (Elaeagnus angustifolia) is an exotic riparian tree and is currently one of the most common woody riparian species in the western United States (Friedman et al. 2005). Russian olive has the capacity to fix nitrogen due to an actinorhizal association, increase riparian soil nitrogen content (DeCant 2008, Follstad Shah et al. 2010), and affect in-stream nutrient dynamics (Mineau et al. 2011). This tree also has the potential to alter stream OM budgets by increasing the flux of leaf litter and reducing in-stream primary production due to shading, particularly when it occurs in monotypic stands, as is now common along streams throughout large regions of the western United States (Fig. 1). In addition, Russian olive litter may be recalcitrant (difficult to break down) and therefore stored or exported rather than processed within the reach. By changing OM inputs and/or quality, this invasive species has the potential to alter the metabolic balance and efficiency of stream ecosystems.

Pre-invasion data on ecosystem function are particularly rare and, because of this, impacts are often evaluated using space-for-time substitution or experimental removals, even though a before-after comparison may be preferable (Blossey 1999). We used an opportunity to revisit a site that was part of an earlier ecosystem study (International Biological Program or IBP; Golley 1993), to conduct a before-after invasion comparison of stream OM dynamics and ecosystem efficiency in response to Russian olive invasion in an arid land stream.

\section{Study area}

Deep Creek is a spring stream in the sagebrush steppe ecoregion, located in southeast Idaho in the northern Great Basin (42.16 $\mathrm{N}, 112.65^{\circ} \mathrm{W} ; 1457 \mathrm{~m}$ elevation). This region has a semiarid climate with mean annual precipitation $\sim 25 \mathrm{~cm}$ (Barton 2004). Multiple reaches of Deep Creek were extensively studied as a representative cool-desert stream during the IBP in the early 1970s (Minshall et al. 1973, Minshall 1978). It has since experienced invasion by Russian olive along some downstream reaches, while some upstream reaches have maintained riparian areas dominated by native grasses, sagebrush (Artemisia tridentata), and patches of narrowleaf willow (Salix exigua). We revisited two of the reaches studied during the IBP: an upstream reference reach, where the riparian vegetation has experienced little change, and a reach invaded by Russian olive since the mid 1980s (Fig. 1), located approximately $8 \mathrm{~km}$ downstream. Both sites are now and were historically managed for cattle grazing, although the frequency of cattle presence has diminished compared to the 1970s (Ken Timothy, personal communication). At the reference reach, reduced grazing has increased the presence and density of narrowleaf willows, although they remain patchy and small. At the invaded reach, Russian olive is dense along approximately $1400 \mathrm{~m}$ (Fig. 1) with a mean of 105 trees on both banks per $100 \mathrm{~m}$ of stream length. Canopy cover at the invaded reach now averages $50 \%$ (measured using a densiometer), compared to $19 \%$ at the reference reach. Mean discharge at the reference reach was $40 \mathrm{~L} / \mathrm{s}$, measured across 18 sampling dates by establishing a cross-section and measuring flow using a Flo-mate flow meter (Hach-Marsh/McBirney, Frederick, Maryland, USA). The stream between the reference and invaded reaches becomes ephemeral but a large spring reestablishes permanent flow just upstream of an irrigation diversion, which is located approximately 200 $\mathrm{m}$ upstream of the reach invaded by Russian olive. This irrigation diversion reduces discharge in the invaded reach during certain portions of the year; mean discharge is $750 \mathrm{~L} / \mathrm{s}$ excluding periods when water is withdrawn for irrigation ( $n=12$ measurements), however, mean discharge in the stream channel is 15 $\mathrm{L} / \mathrm{s}$ when the irrigation diversion is open $(n=6$ measurements). The timing and magnitude of these withdrawals have remained consistent since well before the IBP, and diversions like this one are common in the region; we therefore considered this condition to be consistent with respect to the pre- to post-invasion comparison. 


\section{Methods}

We tested the specific predictions that Russian olive invasion increased allochthonous $\mathrm{OM}$ subsidies to streams, reduced autochthonous primary production, increased stream ecosystem respiration, increased OM storage, increased export of OM, reduced the balance of production to respiration, and reduced ecosystem efficiency with respect to particulate OM. Stream ecosystems were defined at the scale of reaches (200$600 \mathrm{~m}$ ). We measured input, processing, and output of $\mathrm{OM}$ in the invaded and reference reaches (2006-2009) and compared these to pre-invasion conditions measured during the IBP study (1970-1974). We modeled the sampling methods and regime in this study after those of the IBP study; however, we did use some analogous but updated techniques, and in many cases increased the number and duration of measurements.

We measured allochthonous litter in SeptemberDecember 2007 and June-December 2008 using 10 streambank litter baskets $\left(0.2 \mathrm{~m}^{2}\right.$ area and approximately $40 \mathrm{~cm}$ high) at each reach. They were placed at the wetted edge of the stream and distributed in proportion to the frequency of riparian vegetation type in each reach (e.g., $70 \%$ Russian olive, 30\% grass/ sagebrush would result in seven baskets placed under Russian olive and three in open areas). We collected the basket contents approximately biweekly, visually characterized the source of the material, and determined ash free dry mass (AFDM) using standard methods (APHA 2005). During the IBP study, open buckets with a smaller area of $0.06 \mathrm{~m}^{2}$ were suspended over the stream from posts driven into the streambed. Bank traps capture less litter than over-stream traps, so our postinvasion estimate is conservative and may underestimate litter inputs by as much as $10 \%$ (Cirello et al. 1999).

Whole reach gross primary production (GPP) and ecosystem respiration (ER) were measured using the two-station open-channel technique (Marzolf et al. 1994, Young and Huryn 1998). We made 18 and 15 metabolism measurements in the invaded and reference reaches, respectively, between August 2006 and August 2008. Monthly measurements were made between May and November, and less frequent measurements were made between December and April with a minimum of two measurements in each season (see Appendix A for additional methodological details). During the IBP study, a two-station carbon dioxide change method was used, with carbon dioxide concentration inferred from $\mathrm{pH}$ and alkalinity as described in Wright and Mills (1967). We chose to use a different technique because developments in $\mathrm{O}_{2}$ sensors and gas tracer techniques have made dissolved oxygen and reaeration easier to measure, which in this case allowed for more frequent metabolism measurements. The dissolved oxygen and carbon dioxide techniques do not result in significantly different estimates of metabolism (Webster et al. 2005).

We assessed storage of OM by quantifying benthic organic matter (BOM) once during the study. We used
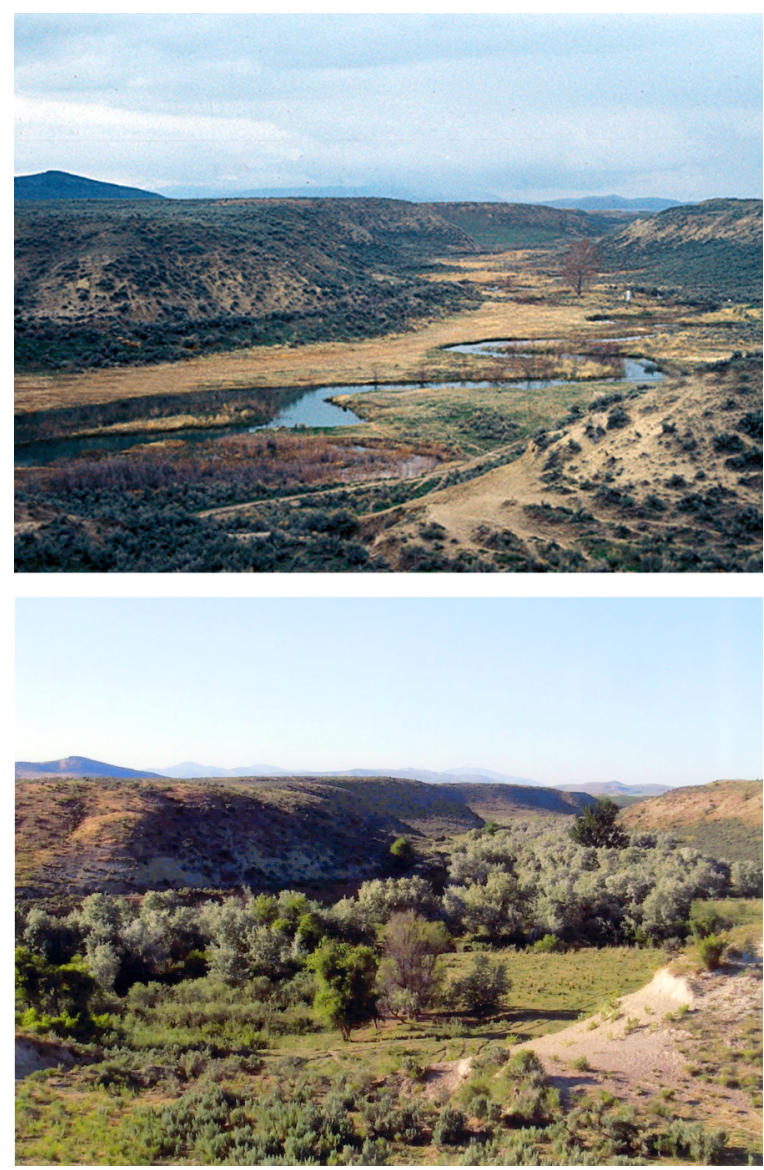

FIG. 1. Deep Creek, Idaho, USA, before (1970, top) and after (2006, bottom) invasion by Russian olive. Photo credits: 1970, G. Wayne Minshall; 2006, Colden Baxter.

both a $314-\mathrm{cm}^{2}$ stove pipe core sampler (Wallace et al. 2006) and a $35-\mathrm{cm}^{2}$ piston corer to sample benthic material to depths of 10 and $20 \mathrm{~cm}$, respectively. We sampled three pools and three riffles using each method in each reach during September 2009. The piston cores were divided into sections by $5-\mathrm{cm}$ increments. Ash-free dry mass (AFDM) was determined for each core section and all material in the stovepipe sample. The measurements from the stovepipe sampler were proportionally scaled to $20 \mathrm{~cm}$ depth using the data obtained from the piston corer samples. Once during the IBP study, a USBMH-53 sampler $\left(20.3 \mathrm{~cm}^{2}\right.$; United States Geological Survey, Hydrological Instrumentation Facility, Stennis Space Center, Mississippi, USA) was used to core to 20 $\mathrm{cm}$ depth and AFDM was determined for the entire core.

To better understand the processing and fate of Russian olive litter once it entered streams, we measured the decomposition rate of leaves from Russian olive and a native willow species (peachleaf willow, Salix amygdaloides) in both study reaches. Allochthonous litter decomposition rates were not measured as part of the IBP study. To measure the decay rate of each type of 
litter, we conducted a litter bag mass loss experiment (see methodological details in Appendix B).

We measured transport of OM into and out of the study reaches 10 times from June 2008 to September 2009. We used triplicate nets $(250 \mu \mathrm{m}$ mesh, $45 \times 35 \mathrm{~cm}$ opening) placed horizontally in the stream perpendicular to the current for 15 minutes per measurement. We measured the water depth and velocity at the net opening once during the first minute of collection using a Flo-mate flow meter and wading rod. The material collected in each net was rinsed in a $250-\mu \mathrm{m}$ mesh sieve and the coarse fraction was sorted visually according to autochthonous or allochthonous origin. If the origin of the material could not be determined, it was categorized as amorphous detritus. AFDM for each type of OM was determined as above. Similar methods were used during the IBP study when eight measurements were conducted between February and September 1974. We report only coarse particulate organic matter (CPOM) drift because data for fine OM drift were not available from the IBP study for the reaches we used. We also attempted to include dissolved organic matter (DOM) in the OM budgets, but adequate data were not available from the IBP study to allow for a before-after comparison. We did measure dissolved organic carbon (DOC) concentrations at the downstream end of each reach between March 2008 and February 2009 (see Appendix C).

We used the data generated by the sampling described above (Table $\mathrm{C} 1$ ) to compile partial annual OM budgets and generate coarse estimates of $\mathrm{EE}$ for each reach during the IBP and in 2007. To calculate annual fluxes of OM (GPP, ER, litter), we scaled measurements to monthly estimates and summed these estimates to obtain yearly values (see Appendix $\mathrm{C}$ for methodological details used in scaling). Particulate OM export is one of the most temporally variable components of stream $\mathrm{OM}$ budgets (Webster and Meyer 1997) so scaling a single monthly measurement would likely not be representative. Due to very large variation (Appendix C; up to four orders of magnitude) in measurements of CPOM drift, we scaled the median value of all measurements for the year to arrive at the most representative annual estimate for this flux. We estimated EE for stream reach budgets as $100 \times(\mathrm{ER} /[\mathrm{GPP}+$ litter input $])($ Webster and Meyer 1997). We used mean DOC concentration (Appendix C: Table C2) and mean discharge to calculate DOM transport, assuming DOM is $50 \%$ carbon, to evaluate the relative contribution of DOM to OM budgets and the sensitivity of our findings to the lack of before-after comparison of this component.

Scale is at once the strength and limitation of wholeecosystem studies. Because we did not have replicate study reaches, we were limited in the statistical approach that could be applied to the data to discern meaningful differences, in spite of potentially large differences between the two time periods and the potential effect of Russian olive invasion on the variables measured. We used randomized intervention analysis (RIA; Carpenter et al. 1989) to evaluate the null hypothesis of no change relative to the reference site for each flux component of the OM budget. RIA was designed expressly for whole ecosystem experiments to detect differences caused by a specific change in one system compared to a reference system (Carpenter et al. 1989). RIA could not be applied to BOM estimates because they were generated by one time-integrated sample rather than a time series, or EE estimates because they were calculated from the annual estimates of other parameters. We used a paired $t$ test to evaluate differences in the litter decay coefficient between leaf types with a significance criterion of $P \leq$ 0.1 because of the small sample size of two reaches.

\section{Results}

Russian olive invasion altered allochthonous, but not autochthonous, inputs in the OM budget (Fig. 2). As hypothesized, allochthonous litter input significantly increased nearly 25 -fold to $301 \mathrm{~g} \mathrm{AFDM} \cdot \mathrm{m}^{-2} \cdot \mathrm{yr}^{-1}$ at the invaded site after Russian olive was established compared to pre-invasion conditions (RIA $P=0.002$ ). Russian olive comprised $97 \%$ of litter at the invaded site. Litter input also increased at the reference site postinvasion, but this increase was an order of magnitude less than the input to the invaded reach $(21 \mathrm{~g}$ AFDM $\left.\cdot \mathrm{m}^{-2} \cdot \mathrm{yr}^{-1}\right)$. Opposite to our prediction, mean GPP actually increased by $51 \%$ in the invaded reach while it remained similar in the reference reach, but this difference was not significant due to high variability among measurements (Fig. 2; RIA $P=0.642$ ).

Contrary to our hypothesis, presence of Russian olive did not significantly alter exports of OM (Fig. 2). Though ER, which is an estimate of OM loss due to organism activity, increased by an average $53 \%$ in the invaded reach and changed little in the reference reach, high variability among measurements meant this difference was not significant (RIA $P=0.685$ ). As a result, the ratio of GPP to ER also remained similar and near 1 in both reaches post-invasion (Fig. 2; RIA $P=0.567$ ). Net reach flux (import minus export) of allochthonous and autochthonous CPOM increased by an order of magnitude at both reaches post-invasion, but we did not detect significant difference in change of the invaded vs. the reference reach (Fig. 2; RIA allochthonous $P=$ 0.354 and autochthonous $P=0.09$ ). In 2008-2009, mean DOM concentration was 3.4 and $2.0 \mathrm{mg} / \mathrm{L}$ (Appendix C: Table C2) and DOM transport was 429 and $39604 \mathrm{~kg} / \mathrm{yr}$ at the reference and invaded sites, respectively.

Russian olive invasion did alter the processing and storage of OM in this stream, with consequences for net ecosystem efficiency. At the invaded site, the BOM storage increased nearly fourfold following Russian olive invasion, whereas it increased by only $30 \%$ at the reference site (Fig. 2). At both sites, Russian olive leaves had a significantly slower decay rate $(k=0.0153$ and $0.0240)$ in the stream than willow leaves $(k=0.0232$ and $0.0367 ; t_{(1)}=4.27 ; P=0.07$; Appendix B). Russian olive leaves retained $20-46 \%$ of their starting AFDM after 53 
FIG. 2. Partial annual organic matter budgets for the (A) reference and (B) Russian olive invaded reaches of Deep Creek, (top) before and (bottom) after invasion. The before-invasion budgets come from work conducted during the International Biological Program (IBP). All inputs and outputs (arrows) are g AFDM. $\mathrm{m}^{-2} \cdot \mathrm{yr}^{-1}$ and mean storage pools (boxes) are g AFDM $/ \mathrm{m}^{2}$. Abbreviations are $P$, production; $R$, respiration; AFDM, ash-free dry mass; CPOM AT, autochthonous coarse particulate organic matter; CPOM AL, allocthonous coarse particulate organic matter; $\mathrm{BOM}$, benthic organic matter; GPP, gross primary production; and ER, ecosystem respiration. The asterisk signifies a significant change according to randomized intervention analysis (RIA; $P=0.05$ ). Note that BOM could not be compared using RIA because it was not measured as a time series.

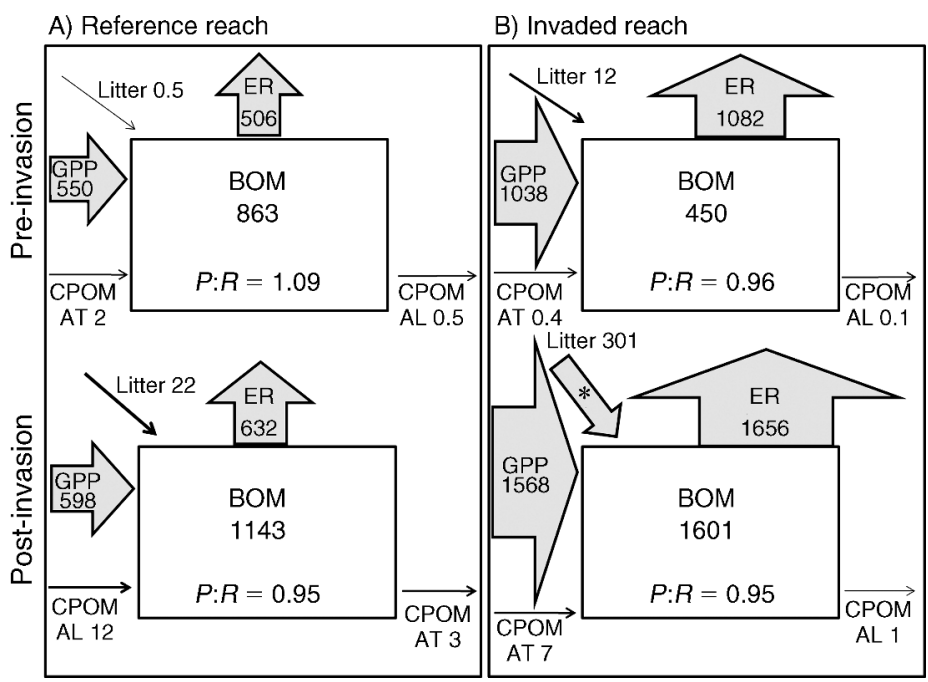

days in the stream whereas willow leaves only retained 14-30\% (Appendix B). Due to the addition of leaf litter that decayed slowly and was stored rather than consumed, EE decreased in the invaded site from 103 to $89 \%$ following Russian olive invasion. In comparison, there was an increase in $\mathrm{EE}$ at the reference site during the study period from 92 to $102 \%$.

\section{Discussion}

We found that a species invasion occurring in one ecosystem can cause functional responses to stress in another closely linked ecosystem. Though a stressor occurs outside of the boundaries of an affected ecosystem, resource subsidies can act as a mechanism to transfer its effect. The addition of relatively recalcitrant Russian olive litter to Deep Creek decreased efficiency of OM processing and increased storage of unused OM. Furthermore, the proportion of the total OM pool in the stream reach from allochthonous sources increased from $1 \%$ to $16 \%$ after Russian olive invasion. In spite of this, we did not observe a significant shift in the ratio of production to respiration $(P: R)$ or increased ER. These results suggest that altered riparian subsidy fluxes due to a tree invasion may represent a stress for the recipient ecosystem. We argue that the magnitude of the stress effect in our study is mediated by particular characteristics of the subsidy itself as well as those of the recipient ecosystem.

Russian olive caused a large increase in allochthonous OM input to Deep Creek, but did not alter autochthonous production. The annual Russian olive litter input at the invaded site was much higher than that measured by Follstad Shah et al. (2010), who reported that Russian olive contributed $5 \%$ (or $20 \mathrm{~g}$ dry mass $\cdot \mathrm{m}^{-2} \cdot \mathrm{yr}^{-1}$ ) of total annual litter flux in mixed Russian olive and cottonwood riparian stands along the Rio Grande. Allochthonous litter input at the invaded site now equals or surpasses that received by some streams in mixed deciduous forests (Benfield 1997). However, it remains on the low end of this range and is less than half of the allochthonous inputs received by archetypal deciduous-forested streams (e.g., Benstead et al. 2009). The nearly 25 -fold increase in allochthonous inputs was not accompanied by a decrease in GPP, despite dramatic increases in shading from the Russian olive canopy. It is possible that this increase in shading was not sufficient to induce light limitation of GPP, due to increased photosynthetic efficiency (Hill et al. 1995).

Differences in GPP, ER, and $P: R$ were not detected via RIA due to high variability among measurements, however, on average, GPP and ER did increase by about $50 \%$ at the invaded site, which may represent ecologically significant changes deserving of further investigation. With respect to GPP, even if there were negative effects due to shading, we reason that this might be offset by potential increases in nitrogen inputs from Russian olive (Mineau et al. 2011), and any subsequently subtle differences in GPP would be difficult to detect given the sample sizes available for comparison in this study. Elsewhere, we have shown that Russian olive is associated with altered nutrient dynamics in streams, including reduction of nitrogen limitation of biofilm chlorophyll- $a$ (Mineau et al. 2011), an observation consistent with a potential increase in GPP. If such an increase did occur, it could increase availability of autochthonous DOM, which, in turn, might explain our observation of an associated, proportional increase in ER. In another desert spring stream, hyporheic ER was stimulated by the addition of autochthonous but not allochthonous OM (Jones 1995). Therefore, OM source and quality appear to determine the fate of this subsidy. Other studies (e.g., Heffernan 2008) have found that alteration of ecosystem function caused by vegetation shifts were driven by geomorphic changes. We did not explicitly monitor geomorphic parameters; however, photographic time series show little change in channel form and we did not observe large differences in mean discharge, width, or depth in either study reach before 

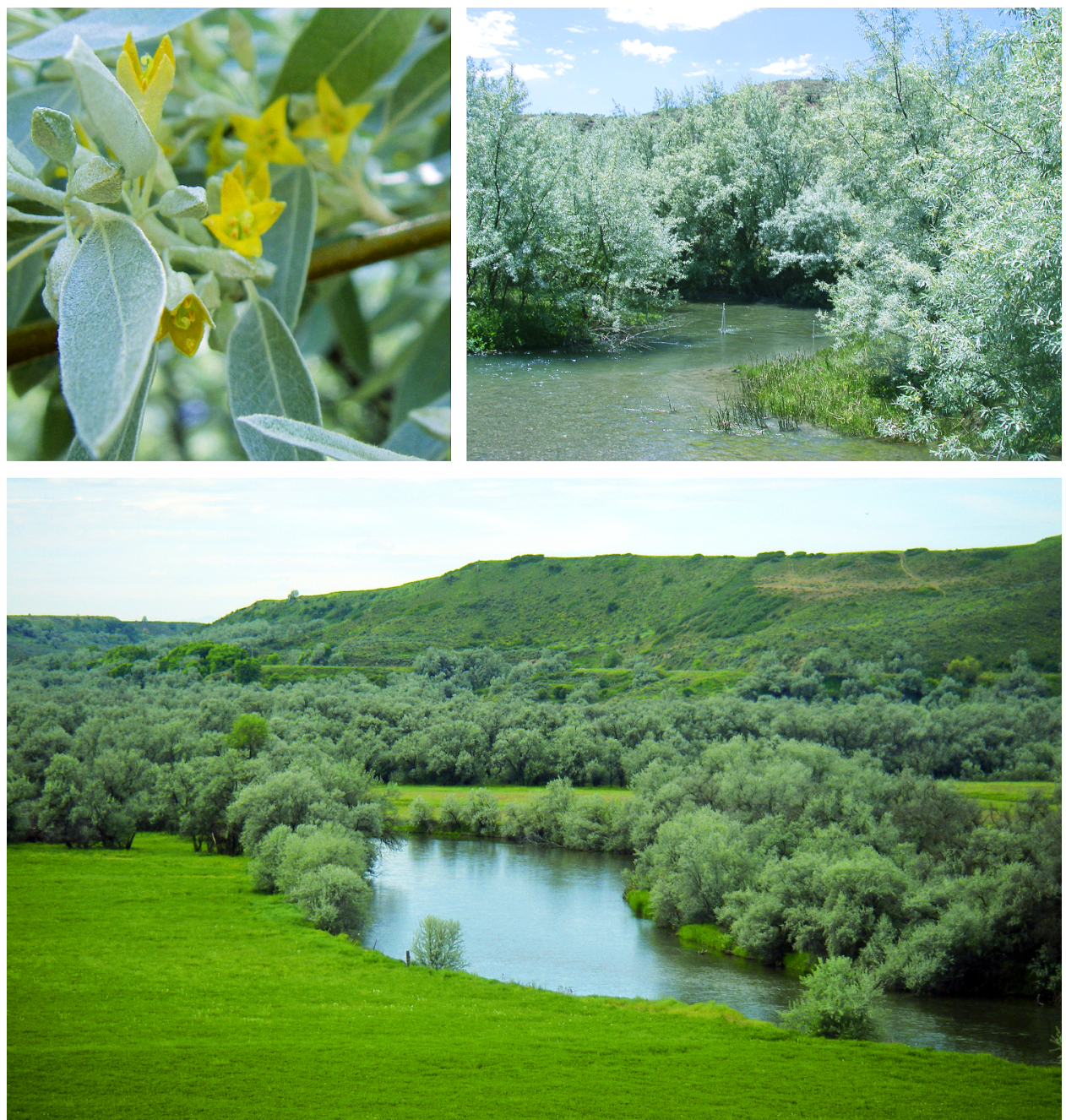

Plate 1. (Upper left) Russian olive foliage and flowers. (Upper right) A thicket of Russian olive lining the banks of the invaded study reach of Deep Creek, Idaho, USA. (Lower) A dense monotypic stand of Russian olive along the Bear River in southeastern Idaho. Photo credits: M. M. Mineau.

and after Russian olive invasion, suggesting these were unlikely drivers of ecological changes we observed.

The non-labile nature of Russian olive litter appears to drive the apparent reduction of stream EE. Willows have a higher leaf $\mathrm{C}: \mathrm{N}$ than Russian olive and might therefore be expected to decompose at a slower rate (Royer et al. 1999, Harner et al. 2009, USDA 2010). However, we found that Russian olive leaf litter broke down more slowly than willow litter in this stream. This may be due to high lignin and structural carbon content in Russian olive leaves (Moline and Poff 2008) or microbial inhibition due to allelochemicals (Llinares et al. 1993). The decay rate measured for Russian olive at the invaded site was similar to others reported in the literature $\left(0.0240 \mathrm{~d}^{-1}\right.$ vs. $0.0176-0.0305 \mathrm{~d}^{-1}$; Royer et al. 1999, Harner et al 2009). However, the decay rate measured for Russian olive litter at the reference site $\left(0.0153 \mathrm{~d}^{-1}\right)$ was lower than those previously reported for this material, perhaps due to low water temperature (Appendix B).

Given the potential importance of DOM to stream organic matter budgets (Webster and Meyer 1997) and that a lack of adequate pre-invasion data prevented a comparison for this component, we used DOC data from recent years to evaluate the effect of this gap on our findings and interpretations. We found that DOM transport is presently a substantial flux of OM in Deep Creek compared to other fluxes and pools reported in the budget, but is relatively small compared to other streams. Though DOM concentrations were greater at the reference site, DOM transport at the invaded site far exceeded it due to higher discharge. In a review, Mulholland (1997) reported mean DOM concentrations of $9.5 \mathrm{mg} / \mathrm{L}$ and mean transport of $7.7 \times 10^{6} \mathrm{~kg} / \mathrm{yr}$ for 33 streams and rivers and mean transport of $1.1 \times 10^{5} \mathrm{~kg} /$ yr, excluding larger rivers (larger than fourth order, $n=$ 8 rivers). In other streams of arid regions, mean DOM 
concentrations ranged from $11.9 \mathrm{mg} / \mathrm{L}$ (Sycamore Creek) to $0.7 \mathrm{mg} / \mathrm{L}$ (Rattlesnake Spring; Mulholland 1997). In forested Appalachian streams, where leaf litter accounts for about $80 \%$ of total OM inputs (Benstead et al. 2009), leaf litter contributes $30 \%$ of stream DOC export (Meyer et al. 1998). Considering that Russian olive leaf litter only represents $16 \%$ of OM inputs at the invaded site, it is likely that DOM in Deep Creek is largely derived from autochthonous sources. As such, we reason that the DOM component of the annualized OM budget would not have been directly affected by Russian olive invasion, though effects of episodic (e.g., during pulsed inputs of leaves) or indirect (e.g., via possible changes in GPP) nature may occur.

The dominant fate of allochthonous OM added by Russian olive at the Deep Creek invaded reach was likely storage as BOM. We observed a fourfold increase in $\mathrm{BOM}$ at the invaded site while $\mathrm{BOM}$ at the reference site increased only $30 \%$. The large BOM pool may only be temporary and may be exported during scouring flows as part of multi-year cycles of accumulation and loss (Wallace et al. 1997a). However, our ability to detect changes in OM export as DOC and CPOM was constrained by the data available from the IBP study and the temporal resolution and/or duration of our investigations. Because we measured OM export episodically during a 16 month period, we may have only measured a period of OM accumulation and failed to capture spate and storm-driven export events (Benstead et al. 2009, Hall et al. 2009). If the large accumulation of stored BOM is exported during such events, it may drive periodic or pulsed OM subsidies to downstream ecosystems.

The resilience of stream EE to such changes in riparian structure is not known, and additional longterm and/or manipulative studies are needed for it to be quantified. The decrease in EE apparently caused by Russian olive invasion may persist as an alternative stable state (Scheffer et al. 2001) or the change may be temporary and EE may rebound if the aquatic community adapts to utilize the novel OM source. Regardless, our findings contribute to the growing body of evidence that alterations in riparian vegetation are the driver of major ecological change in arid streams, potentially shifting these ecosystems to an alternative stable state (e.g., Heffernan 2008, Ball et al. 2010). This highlights the need to use a holistic approach, considering aquatic and riparian systems together, in management and restoration decisions.

\section{ACKNOWLEDGMENTS}

We thank the U.S. Forest Service, Caribou National Forest, Malad, Idaho, USA, for granting access to study sites. Thanks to ISU Stream Ecology Center students and technicians for assistance with field sampling and laboratory processing. We are indebted to all who contributed to the IBP study at Deep Creek. We thank Michelle Baker, Richard Inouye, Benjamin Crosby, and two anonymous reviewers for helpful reviews of the manuscript. Thanks also to John Davis and Neil Olson for help with RIA and Matlab. Funding for this research was provided by NSF EPSCoR in Idaho (EPS 04-47689, 08-14387) and an NSF Doctoral Dissertation Improvement Grant (DEB 09-10367).

\section{Literature Cited}

APHA. 2005. Standard methods for the examination of water and wastewater. American Public Health Association, Washington, D.C., USA.

Ball, B. A., J. S. Kominoski, H. S. Adams, S. E. Jones, E. S. Kane, T. D. Loecke, W. M. Mahaney, J. P. Martina, C. M. Prather, T. M. P. Robinson, and C. T. Robinson. 2010. Direct and terrestrial vegetation-mediated effects of environmental change on aquatic ecosystem processes. BioScience 60:590-601.

Barton, B. J. 2004. Surface- and ground-water relations on the Portneuf River, and temporal changes in ground-water levels in the Portneuf Valley, Caribou and Bannock counties, Idaho, 2001-02. USGS Report 2004-5170. U.S. Geological Survey, Reston, Virginia, USA.

Baxter, C. V., K. D. Fausch, M. Murakami, and P. L. Chapman. 2004. Fish invasion restructures stream and forest food webs by interrupting reciprocal prey subsidies. Ecology 85:2656-2663.

Benfield, E. F. 1997. Comparison of litterfall input to streams. Journal of the North American Benthological Society 16:104-108.

Benstead, J. P., A. D. Rosemond, W. F. Cross, J. B. Wallace, S. L. Eggert, K. Subberkropp, V. Gulis, J. L. Greenwood, and C. J. Tant. 2009. Nutrient enrichment alters storage and fluxes of detritus in a headwater stream ecosystem. Ecology 90:2556-2566

Blossey, B. 1999. Before, during and after: the need for longterm monitoring in invasive plant species management. Biological Invasions 1:301-311.

Busch, D. E., and S. G. Fisher. 1981. Metabolism of a desert stream. Freshwater Biology 11:301-307.

Carpenter, S. R., T. M. Frost, D. Heisey, and T. K. Kratz. 1989. Randomized intervention analysis and the interpretation of whole-ecosystem experiments. Ecology 70:1142-1152.

Cirello, C., I. Pardo, and E. S. Lopez. 1999. Comparison of riparian vs. over stream trap location in the estimation of vertical litterfall inputs. Hydrobiologia 416:171-179.

DeCant, J. P. 2008. Russian olive, Elaeagnus angustifolia, alters patterns in soil nitrogen pools along the Rio Grande River, New Mexico, USA. Wetlands 28:896-904.

Fausch, K. D., C. V. Baxter, and M. Murakami. 2010. Multiple stressors in north temperate streams: lessons from linked forest-stream ecosystems in northern Japan. Freshwater Biology 55:120-134.

Fisher, S. G., N. B. Grimm, E. Marti, J. Jones, and R. Holmes. 1998. Material spiraling in stream corridor ecosystems: a telescoping ecosystem model. Ecosystems 1:19-34.

Follstad Shah, J. J., M. J. Harner, and T. M. Tibbets. 2010. Elaeagnus angustifolia elevates soil inorganic nitrogen pools in riparian ecosystems. Ecosystems 13:46-61.

Foster, D. R., J. D. Aber, J. M. Melillo, R. D. Bowden, and F. A. Bazzaz. 1997. Forest response to disturbance and anthropogenic stress. BioScience 47:37-445.

Friedman, J. M., G. T. Auble, P. B. Shafroth, M. L. Scott, M. F. Merigliano, M. D. Preehling, and E. K. Griffin. 2005. Dominance of non-native riparian trees in western USA. Biological Invasions 7:747-751.

Golley, F. B. 1993. A history of the ecosystem concept in ecology: More than the sum of the parts. Yale University Press, New Haven, Connecticut, USA.

Gregory, S. V., F. J. Sawanson, W. A. McKee, and K. W. Cummins. 1991. An ecosystem perspective of riparian zones. BioScience 41:540-551.

Hall, R. O., M. A. Baker, C. D. Arp, and B. J. Koch. 2009. Hydrologic control of nitrogen removal, storage, and export in a mountain stream. Limnology and Oceanography 54:2128-2142. 
Harner, M. J., C. L. Crenshaw, M. Abelho, and M. Stursova, J. J. Follstad Shah, and R. L. Sinsabaugh. 2009. Decomposition of leaf litter from a native tree and an actinorhizal invasive across riparian habitats. Ecological Applications 19:1135-1146

Heffernan, J. B. 2008. Wetlands as an alternative stable state in desert streams. Ecology 89:1261-1271.

Hill, W. R., M. G. Ryon, and E. M. Schilling. 1995. Light limitation in a stream ecosystem: Responses by primary producers and consumers. Ecology 76:1297-1309.

Jones, J. B. 1995. Factors controlling hyporheic respiration in a desert stream. Freshwater Biology 34:91-99.

Kennedy, T. A., and S. E. Hobbie. 2004. Saltcedar (Tamarix ramosissima) invasion alters organic matter dynamics in a desert stream. Freshwater Biology 49:65-76.

Likens, G. E., F. H. Bormann, N. M. Johnson, D. W. Fisher, and R. S. Pierce. 1970. Effects of forest cutting and herbicide treatment on nutrient budgets in the Hubbard Brook watershed-ecosystem. Ecological Monographs 40:23-47.

Llinares, F., D. Muñoz-Mingarro, J. M. Pozuelo, B. Ramos, and F. Bermuidez de Castro. 1993. Microbial inhibition and nitrification potential in soils incubated with Elaeagnus angustifolia L. leaf litter. Geomicrobiology Journal 11:149156.

Marcarelli, A. M., C. V. Baxter, M. M. Mineau, and R. O. Hall, Jr. 2011. Quantity and quality: unifying food web and ecosystem perspectives on the role of resource subsidies in freshwaters. Ecology 92:1215-1225.

Marzolf, E. R., P. J. Mulholland, and A. D. Steinman. 1994 Improvements to the upstream-downstream dissolved oxygen change technique for determining whole-stream metabolism of small streams. Canadian Journal of Fisheries and Aquatic Sciences 51:1591-1599.

Meyer, J. L., J. B. Wallace, and S. L. Eggert. 1998. Leaf litter as a source of dissolved organic carbon in streams. Ecosystems $1: 240-249$

Mineau, M. M., C. V. Baxter, and A. M. Marcarelli. 2011. A non-native riparian tree (Elaeagnus angustifolia) changes nutrient dynamics in streams. Ecosystems 14:353-365.

Minshall, G. W. 1978. Autotrophy in stream ecosystems. BioScience 28:767-771.

Minshall, G. W., D. A. Andrews, F. L. Rose, D. W. Shaw, and R. L. Newell. 1973. Validation studies at Deep Creek, Curlew Valley. US/IBP Desert Biome RM 73-48. U.S. International Biological Program, Desert Biome, Logan, Utah, USA.

Moline, A. B., and N. L. Poff. 2008. Growth of an invertebrate shredder on native (Populus) and non-native (Tamarix, Elaeagnus) leaf litter. Freshwater Biology 53:1012-1020.

Mulholland, P. J. 1997. Dissolved organic matter concentrations and flux in streams. Journal of the North American Benthological Society 16:131-141.

Nakano, S., H. Miyasaka, and M. Kuhara. 1999. Terrestrialaquatic linkages: riparian arthropod inputs alter trophic cascades in a stream food web. Ecology 80:2435-2441.
Odum, E. P. 1985. Trends expected in stressed ecosystems. BioScience 35:419-422.

Rappaport, D. J., H. A. Regier, and T. C. Hutchinson. 1985. Ecosystem behavior under stress. American Naturalist 125:617-640.

Royer, T. V., M. T. Monaghan, and G. W. Minshall. 1999. Processing of native and exotic leaf litter in two Idaho (USA) streams. Hydrobiologia 400:123-128.

Scheffer, M., S. Carpenter, J. A. Foley, C. Folk, and B. Walker. 2001. Catastrophic shifts in ecosystems. Nature 413:591-596.

USDA. 2010. PLANTS Database. U.S. Department of Agriculture Natural Resources, Conservation Service, Washington, D.C., USA. http://plants.usda.gov/

Vitousek, P. M., C. M. D’Antonio, L. L. Loope, M. Rejmanek, and R. Westbrooks. 1997. Introduced species: a significant component of human-caused global change. New Zealand Journal of Ecology 21:1-16.

Wallace, J. B., T. F. Cuffney, S. L. Eggert, and M. R. Whiles. 1997a. Stream organic matter inputs, storage, and export for Satellite Branch at Coweeta Hydrologic Laboratory, North Carolina, USA. Journal of the North American Benthological Society 16:64-74.

Wallace, J. B., S. L. Eggert, J. L. Meyer, and J. R. Webster. 1997b. Multiple trophic levels of a forest stream linked to terrestrial litter inputs. Science 277:102-104.

Wallace, J. B., J. J. Hutchens, Jr., and J. W. Grubaugh. 2006. Transport and storage of FPOM. Pages 249-272 in F. R. Hauer and G. A. Lamberti, editors. Methods in stream ecology. Second edition. Academic Press, San Diego, California, USA.

Webster, I. T., N. Rea, A. V. Padovan, P. Dostine, S. A. Townsend, and S. Cook. 2005. An analysis of primary production and the Daly River, a relatively unimpacted tropical river in northern Australia. Marine and Freshwater Research 56:303-316.

Webster, J. R., M. Gurtz, J. Hains, J. L. Meyer, W. Swank, J. Waide, and J. B. Wallace. 1983. Stability of stream ecosystems. Pages 355-395 in J. R. Barnes and G. W. Minshall, editors. Stream ecology. Plenum Publishing, New York, New York, USA.

Webster, J. R., and J. L. Meyer. 1997. Organic matter budgets for streams: a synthesis. Journal of the North American Benthological Society 16:141-161.

Wetzel, R. G. 1995. Death, detritus, and energy flow in aquatic ecosystems. Freshwater Biology 33:83-89.

Wright, J. C., and I. K. Mills. 1967. Productivity studies on the Madison River, Yellowstone National Park. Limnology and Oceanography 12:568-577.

Young, R. G., and A. D. Huryn. 1998. Comment: improvements to the diurnal upstream-downstream dissolved oxygen change technique for determining whole-stream metabolism in small streams. Canadian Journal of Fisheries and Aquatic Sciences 55:1784-1785.

\section{Supplemental Material}

\section{Appendix A}

Additional methodology of metabolism measurements (Ecological Archives E093-133-A1).

\section{Appendix B}

Additional methodology and results for litter decomposition experiment (Ecological Archives E093-133-A2).

\section{Appendix C}

Additional OM budget methodology and data (Ecological Archives E093-133-A3). 